\title{
Cara Mengkonsumsi Makanan Yang Halal Lagi Baik Menurut Konsep Islam dan Pemerintah Indonesia
}

\author{
Muharir \\ Program Studi Ekonomi Syariah STEBIS IGM Palembang \\ Email : muharir@stebisigm.ac.id
}

\begin{abstract}
Indonesia is one of the countries with the largest Muslim majority in the world. As many as $87.18 \%$ of the 237,641,326 population of Indonesia are Muslims. As the fact is that the majority of Indonesia's population is Muslim, Islam has greatly influenced the developing culture. Including the pattern of consumerization among Indonesians is very much influenced by Islam. The pattern of consumerization is comprehensive. One of them is the pattern of people's consumption of food ingredients. The phenomenon that occurs in connection with this is that the public understands the importance of consuming halal products, but does not have an accurate basis to be used as a reference for the halalness of a product. In the above explanation, it can be concluded that the Indonesian Ulema Council (MUI) has certified halal products and MUI has also labeled halal products, meaning that consuming good, halal food has been tried to the maximum by the government by taking the form of consumer protection and protection. With this the author wants to socialize about how to Consume Halal Food Again according to the Concept of Islam and the Indonesian Government
\end{abstract}

Keywords : Halal food according to Islam, halal

\begin{abstract}
Abstrak
Indonesia merupakan salah satu negara yang memiliki penduduk dengan mayoritas beragama Islam terbesar di dunia. Sebanyak 87,18 \% dari 237.641 .326 penduduk Indonesia adalah pemeluk agama Islam. Sebagaimana kenyataannya bahwa mayoritas penduduk Indonesia adalah Muslim, maka agama Islam sangat berpengaruh terhadap kultur yang berkembang. Termasuk pola konsumerisasi dikalangan masyarakat Indonesia sangat dipengaruhi oleh agama Islam. Pola konsumerisasi mencakup banyak hal. Salah satunya adalah pola konsumsi masyarakat terhadap bahan makanan. Fenomena yang terjadi berkaitan dengan hal tersebut adalah masyarakat paham akan pentingnya konsumsi produk halal, namun tidak mempunyai landasan yang akurat untuk dijadikan acuan kehalalan suatu produk. Pada penjelasan diatas maka dapat di tarik kesimpulan bahwa majlis ulama Indonesia ( MUI ) telah mensertivikasi produk halal dan MUI juga telah melebelisasi produk halal, artinya mengkonsumsi makanan yang halal lagi baik telah di usahakan semaksimal mungkin oleh pemerintah dengan melakukan bentuk proteksi dan perlindungan konsumen. Dengan ini penulis ingin mensosialisasikan tentang bagaimana Cara Mengkonsumsi Makanan Yang Halal Lagi Baik Menurut Konsep Islam dan Pemerintah Indonesia.
\end{abstract}

Kata Kunci: $\quad$ Makanan Yang Halal Menurut Islam, halal 


\section{Pendahuluan}

Kebanyakan dari masyarakat mempercayai produk halal hanya dari ucapan penjual atau logo halal yang dibuat oleh perusahaan produk makanan. Konsumen kini disuguhi banyak pilihan produk, salah satunya adalah produk pangan dalam kemasan. Sejumlah langkah bisa ditempuh konsumen saat mempertimbangkan untuk mengkonsumsi sebuah produk dalam kemasan. Misalnya, dengan memperhatikan label produk kemasan. Ini untuk memastikan kelayakan produk dan status kehalalannya. Di zaman sekarang ini masyarakat dalam mengkonsumsi produk pangan lebih memperhatikan tanggal kadaluarsa dari pada label halal. Kondisi masyarakat Indonesia yang awam tentang produk halal dan haram, sebagian besar masyarakat bersikap masa bodoh dalam mengkonsumsi berbagai macam produk yang ada di pasaran. Terlebih lagi sosialisasi tentang produk berlabel halal masih sangat kurang. Artinya masih sebagian orang saja yang sadar akan pentingnya label halal tersebut yang akan mencari tahu status kehalalan produk yang dikonsumsinya. Label merupakan alat penyampaian informasi tentang produk yang tercantum pada kemasan. Sedangkan kehalalan adalah sebagai parameter utama dalam proses pemilihan produk. Ketentuan membuat keterbatasan pada suatu produk untuk memasuki pasar umut Muslim. Memastikan makanan yang dikonsumsi halal menjadi tanggung jawab bagi setiap muslim.

Untuk mempermudah mengetahui produk yang dikonsumsi halal dalam kemasan maka dapat dilihat dari label halal yang tercantum pada kemasan produk tersebut. Bukit tinggi merupakan kota terbesar kedua di provinsi Sumatera Barat yang memiliki jumlah penduduk yang padat dan beraneka ragam, yaitu terdiri dari lapisan masyarakat, agama serta terdiri dari berbagai suku adat. Hal ini menyebabkan muncul produsen dan konsumen yang beraneka ragam pula. Sehingga produk yang tersedia di pasaran beraneka ragam, baik jenis maupun jumlahnya. Kota Bukittinggi adalah kota bersejarah bagi Majelis Ulama, kota tempat pertama lahirnya Majelis Ulama ditahun 60 an, cikal bakal terbentuknya Majelis Ulama Indonesia oleh Buya Hamka. Saat ini Kota Bukittinggi telah mempunyai RPH bersertifikat halal dan telah lebih dari 60 produk makanan berlabel halal MUI. Bukittinggi juga merupakan pusat perdagangan terbesar di Sumatera Barat dan banyaknya industry rumah tangga. Akibatnya masyarakat banyak suguhi oleh berbagai macam jenis produk yang ada di pasaran terutama produk dalam kemasan baik produk pangan, kosmetik maupun obat-obatan. Kurang lebih sekitar $60 \%$ produk di pasaran yang telah memiliki label halal.

\section{Metode Pengabdian}

Pada rumusan masalah telah dituliskan bagaimana Mengkonsumsi Makanan Yang Halal Lagi Baik Menurut Konsep Islam dan Pemerintah Indonesia untuk para anggota KPM PKh di Desa Sidomulyo Kec. Air Kumbang. Ekonomi yang terjadi saat ini dimasa pandemi Corona atau Covid 19 ini sangat mempengaruhi keadaan sosial ekonomi masyarakat Indonesia terutama masyarakat Desa Sidomulyo Kecamatan Air Kumbang Kabupaten Banyuasin. Untuk mengetahui bagaimana Mengkonsumsi Makanan Yang Halal Lagi Baik Menurut Konsep Islam dan Pemerintah Indonesia untuk para anggota KPM PKh di Desa Sidomulyo Kec. Air Kumbang .Sebagai bahan untuk mensosialisasikan langkahlangkah yang dilakukan adalah:

1. Memilih tempat yang mau disosialisasi oleh tim PKM

2. Merumuskan metode sosialisasi 
3. Masyarakat disiapkan untuk bertanya kepad tim PKM

\subsection{Tahap Persiapan}

Dalam melakukan sosialisasi tim PKM melakukan persiapan:

1. Materi yang akan disampaikan

2. Gambaran tentang mengkonsumsi produk halal menurut kosnsep Islam dan Pemerintah Indonesia.

3. Hard Copy materi yang akan disampaikan.

\subsection{Tahap Pelaksanaan}

Pada bab sebelumnya, dikegiatan PKM ini adalah memberikan sosialisasi kepada masyarkat Desa Sidomulyo Kecamatan Air Kumbang Kabupaten Banyuasin. Dengan adanya sosialisasi ini diharapkan masyarakat di Kecamatan Air Kumbang, dan KPM PKh mampu memahami tentang bagaimana cara mengkonsumsi makanan yang halal lagi baik menurut konsep islam dan pemerintah Indonesia. Sebelum melaksanakan kegiatan sosialisasi ini tim PKM melukan observasi, diskusi dengan kepala desa, Kecamatan Air kumbang, kemudian tim PKM menentukan sasaran PKM, kemudian dilanjukan dengan konsultasi dengan Pendamping PKH Kecamatan Air Kumbang. Dan rumah Ketua KPM PKH sebagai tempat sosialisasi tim PKM nantinya. Pelaksanaan kegiatan ini dilaksanakan pada tanggal 30 Juni 2020 dimulai pukul 09:00 s/d 11:00 dengan tahapan kegiatan mulai dari pengertin apa itu barang yang halal dan haram menurut konsep Islam secara umum, sistem ekonomi secara umum dan samapi dengan tentang bagaimana cara mengkonsumsi makanan yang halal lagi baik menurut konsep Islam dan Pemerintah Indonesia.

\subsection{Sasaran}

Sasaran dari kegiatan tim PKM adalah masyarakat, anggota KPM PKH Kec. Air kumbang. Dengan bentuk kegiatannya adalah sosialisasi tengang. Mengkonsumsi Makanan Yang Halal Lagi Baik Menurut Konsep Islam dan Pemerintah Indonesia. Peserta yang hadir rata- rata merka yang sudah berumur 30 S s/d 50 tahun.

\section{Hasil dan Pembahasan}

\subsection{Cara mengkonsumsi makanan yang halal menurut Islam}

Dari hasil sosialisasi yang dilakukan bahwa selama proses dilaksanakan sosialisasi ini masyarakat memiliki antusias yang sangat besar dalam menyikapi, mendengar dan memahami Mengkonsumsi Makanan Yang Halal Lagi Baik Menurut Konsep Islam dan Pemerintah Indonesia. Karena begitu banyak manfaat yang didapat oleh masyarakat bahwa pola menkonsumsi makanan yang halal lagi baik merupan solusi untuk kemaslahatan umat. Dengan demikian pola konsumsi makanan dan minuman masyarakat Sidomulyo diharapkan sesuai dengan tuntunan syariat Islam dan pmerintah Indonesia.

Mengkonsumsi makanan yang halal lagi baik merupakan salah satu pola kehidupan yang baik dan cara mempertahankan hidup yang baik karena dengan kita mengkonsumsi makanan yang halal lagi baik maka kita akan terhindar dari perbuatan syetan dan menjadi orang-orang yang merugi dunia maupun diakhirat. Dan orang yang melakukan pola konsumsi yang sesuai dengan tuntunan Syariat 
Islam dan Pemerintah Indonesia akan memperoleh manfaat diantaranya sebagai berikut:

1. Memeliki pedoman yang jelas

2. Prinsip ekonomi yang bersumber langsung dari tuhan

3. Dapat terhindar dari perbuatan syetan seperti sifat boros dan mubadzir

4. Memberikan efek pengendalian diri

5. Memiliki dasar pemikiran yang jelas dan terarah.

\subsection{Roandown acara}

\subsubsection{Tempat dan Waktu Kegiatan}

Kegiatan ini dilaksanakan di Desa Sidomulyo Kecamatan Air Kumbang sosialisasi ini dilakukan pada Hari/ Tanggal: senis dan selasa/ 16-17 November 2020

\subsubsection{Waktu Kegiatan dan Materi Pokok dalam Kegiatan}

Pelaksanaan kegiatan ini dilakukan selama dua (2) hari yaitu hari SeninSelasa. Adapun jadwalnya adalah sebagai berikut :

Tanggal 16 November2020

\begin{tabular}{|c|l|l|}
\hline Waktu & \multicolumn{1}{|c|}{ Materi } & \multicolumn{1}{c|}{ Narasumber } \\
\hline $08.00 .-08.30$ & Registrasi peserta & Rosyid \\
\hline $08.30 .-10.00$ & Pembukaan & Miftah \\
02.00.-10.00. & $\begin{array}{l}\text { Memahami tentang makanan yang } \\
\text { halal lagi baik menurut syariat } \\
\text { Islam. }\end{array}$ & Muharir, S.E.I, M.E.Sy \\
\hline $10.00-11.00$ & Tanya jawab materi & Mode rator \\
\hline $11.00 .-12.30$ & ISHOMA & \\
\hline $12.30-13.30$ & $\begin{array}{l}\text { Halal menurut MUI dan Pemerintah } \\
\text { Indonesia. }\end{array}$ & Muharir, S.E.I, M.E.Sy \\
\hline $13.30-14.00$ & Tanya jawab materi & Moderator \\
\hline $14.00-14.30$ & Penutup dan pembacaan do'a & Ust. Sodikin dan MC \\
\hline
\end{tabular}

\subsection{Evaluasi}

Kegiatan awal yang dilakukan, yaitu berkoordiansi dengan Kades desa Sidomulyo Kecamatan Air kumbang, dan kepala dengan Pendamping PKH kecamatan Air Kumbang dan dengan Ketua Kelompok KPM PKh Desa Sidomulyo Kecamatan Air Kumbang. Setelah melakukan koordinasi dan diskusi, selanjutnya melakukan observasi dan melihat kondisi tempat, serta jumlah masyarakat. Tim PKM selanjutnya memilih tempat Rumah Ketua KPM PKh sebagai tempat sosialisasi kegiatan PKM di desa sidoulyo Kecamatan Air Kumbang Kab. Banyuasin. Kegiatan ini dilaksanakan pada tanggal 30 Juni pad pukul 09:00 s/d 11:00 dan Alhamdulillah dapat berjalan dengan lancar, dan peserta dapat mengikutinya dengan baik dan materipun dapat tersampaikan dengan paripurna namun banyak pertanyaan yang belum dapat terjawab karena keterbatasan waktu. 


\section{Simpulan}

Sebagai akhir dari laporan tim Pengabdian Kepada Masyarakat, maka dapat disimpulkan sebagai berikut : Sosialisasi ini memberikan pemahaman kepada masyarakat tentang Cara Mengkonsumsi Makanan Yang Halal Lagi Baik Menurut Konsep Islam dan Pemerintah Indonesia den dengan hasil $80 \%$ masyarakat dapat memahaminya dengan baik dan $20 \%$ masih dalah tahap bimbingan dan pembinaan berikutnya

\section{Daftar Pustaka}

Aravik, H. 2016. Ekonomi Islam: Konsep, Teori, dan Aplikasi serta Pandangan Pemikir Ekonomi Islam dari Abu Ubaid sampai Al-Maududi. Malang: Empat Dua.

Asmawi. 2011. Perbandingan Ushul Fiqh. Jakarta: Amzah.

Affendi, Satria dan M. Zein. 2005. Ushul Fiqh. Prenada Media. Jakarta

Dzulham, 2018. Negara- Negara Dalam Perlindungan Konsumen Muslim Terhadap Produk Halal, Jakarta Timur.

Jumantoro, Totok dan Samsul Munir Amin. Kamus Ilmu Ushul Fiqih. Jakarta:Amzah

https://elmisbah.wordpress.com/al-maslahah/pengertianalmaslahah

Makalah.blogspot.com/2014/10/makalah-mashlahah-al-mursalah.html 
Сага Mengkonsumsi Makanan Yang Halal Lagi Baik Menurut

Konsep Islam dan Pemerintah Indanesia

Muharir 